\title{
MORALNA PRZESTRZEŃ PRACY A ETYKA ZAWODOWA
}

\section{WSTĘP}

Żyjemy w czasach dominującej skłonności do wartościowania wszystkiego przez pryzmat skuteczności, względnie efektywności mierzonej matematycznie. Racjonalność pragmatyczna (instrumentalna) zdaje się przenikać wszystkie dziedziny naszych działań, tracąc wzgląd na - wydawałoby się - bezużyteczny i kłopotliwy wymiar moralno-humanistyczny. Ten zaś jednak pojawia się, bo życie upomina się o respekt dla moralnego wymiaru międzyludzkich stosunków, w tym także o szacunek dla indywidualnej pracy, o reguły fair play we współpracy oraz wymianie owoców pracy i współdziałania (organizacji). Remedium na zaburzenia i patologie w tej sferze najczęściej upatruje się w psychotechnicznych i socjotechnicznych metodach pobudzania motywacji do pracy lub eliminacji konfliktów w sferze kooperacji i wymiany. W sumie zwykle chodzi o to, aby praca i współpraca stawały się bardziej efektywne, bardziej opłacalne wymierne na skali zysku. Jeśli wprowadza się etyczny punkt widzenia, to przede wszystkim dlatego, że on się opłaca. Dobry wizerunek organizacji też się opłaca. Można więc śmiało powiedzieć, że etyka opłaca się. Czyż można znaleźć lepsze argumenty za wdrażaniem standardów etycznych w moralnej przestrzeni stosunków pracy i współpracy? Problem sprowadza się do odpowiedzi na pytanie: Czy jakikolwiek inny punkt widzenia należy jeszcze w stosunkach pracy i współpracy brać pod uwagę? Przecież pomijając respekt dla etyki czy stosowanie się do zasad społecznej odpowiedzialności biznesu, pozostajemy w obrębie racjonalności ekonomicznej i jej miar wartości. Wszystko wydaje się proste: dobre ludzkie stosunki opłacają się.

Ujmijmy rzecz dokładniej i zauważmy, że proces pracy i stosunki pracy - słowem wszystko, co wypełnia społeczną przestrzeń pracy - postrzega się z różnych perspektyw, przy czym każda zwraca uwagę na to, co najważniejsze dla niej. Pracę oraz miejsce pracy analizuje się i ocenia zatem z perspektywy: 1) ergonomicznej (biorąc pod uwagę poręczność, warunki sprawnej i nieszkodliwej dla zdrowia, 
efektywnej pracy); 2) ekonomicznej (skupiając się na wydajności pracy, jej produktywności); 3) prakseologicznej (uwzględniając jej skuteczność, sprawność ze względu na założony cel); 4) organizacyjnej (rozważając ją pod kątem mechanizmów współpracy, kompatybilności wysiłków pracowniczych względem celu zespołowego); 5) medycznej (dbając o relację pracy do zdrowia, przestrzegania zasad bhp); 6) społecznej (traktując miejsce pracy jako zasadniczą przestrzeń współdziałania i komunikowania się ludzi o różnych interesach, kulturze, religii, języku); 7) psychologicznej (pamiętając, że w miejscu pracy funkcjonuje ludzka psychika z jej zdolnością koncentracji na zadaniach i reagowania na zmienne sytuacje oraz na monotonię wykonywanych czynności, ale także i to, że tu kształtuje się poczucie osobistej i zawodowej ważności, godności); 8) prawnej (bo stosunek pracy uregulowany jest przepisami prawa). I wreszcie na koniec - choć można jeszcze przywoływać inne aspekty analizy i oceny pracy -9) praca i miejsce pracy mogą być oceniane w perspektywie moralnej oraz etycznej (przy czym najczęściej nie bardzo wiadomo, czym i czy w ogóle różnią się perspektywa moralna i etyczna).

Zadaniem etyki jako filozoficznej (całościowej) teorii pojmowania i wartościowania ludzkiej pracy jest wyważenie znaczeń i kryteriów wartościowania poszczególnych odniesień do pracy. Ta zaś traktowana jest przez aksjologów jako wartość niepełna, powiązana ze splotami innych wartości (zespołami celów i środków), toteż ważne jest, aby dostrzec i ocenić właściwe znaczenie i wartość pracy samej w sobie i - ze względu na szerszy jej kontekst aksjologiczny - nie ulega przy tym doraźnym, jednowymiarowym jej ujęciom. W tym celu warto uporządkować, na użytek być może nie tylko tego tekstu, dość istotne dla wartościowania pracy i etyki zawodowej pojęcia i perspektywy. Należą do nich: 1) zrozumienie zróżnicowania pojęć etyki i moralności, 2) analiza kryteriów wartościowania pracy, 3) kwestia form i problemów zarządzania klimatem moralnym w stosunkach pracy.

\section{ETYKA A MORALNOŚĆ}

Od razu muszę się zastrzec, że jakkolwiek moralność i etyka wydają się zjawiskami homogenicznymi (jednorodnymi), to będę starał się różnicować znaczenie tych pojęć, a różnica ta dla tych rozważań będzie traktowana jako istotna. Etyka rozumiana jest potocznie jako akceptowany społecznie zbiór norm moralnych, charakteryzujący się mniejszym lub większym stopniem ich uporządkowania oraz uzasadnienia. Etyka to także filozoficzna nauka dotycząca moralności, porządkująca funkcjonujące przekonania etyczne, nadająca im postać systemów, które przywoływane są jako modele idealne dla kształtowania stosunków moralnych. Historycznie etyka rozwinęła się $\mathrm{z}$ refleksji nad etosem, czyli ludzkim charakterem wypracowanym w procesie przyzwyczajenia, usposobieniem do postępowania 
uważanego za dobre. Charakter (etos) miał dla starożytnych greckich wymiar konkretny, sprowadzający się do wymogów stawianych ról społecznych (władcy, wojownika, rzemieślnika, męża, żony, polityka, obywatela), a dopiero z czasem dramaturdzy i filozofowie greccy uczynili owe cnoty przedmiotem refleksji, odnosząc je do człowieka w ogóle, analizując jego powinności jako człowieka. Przez wieki wszystkie próby konkretyzacji moralnych obowiązków człowieka ze względu na pełnione funkcje społeczne i zawodowe były dedukowane z najogólniejszej powinności bycia człowiekiem. Przestrzeń specjalizacji i specyfikacji ról społecznych zarazem poszerzała się i różnicowała do tego stopnia, że zaczęły rozwijać się etyki zawodowe. Ich funkcja zaczęła być doceniana, kiedy spostrzeżono w etyce zawodowej ważny instrument zarządzania postawami ludzi funkcjonujących w określonym zawodzie, co w znacznym stopniu wyznaczało ich pozycję życiową. Współczesny świat nadał etyce jeszcze jedną funkcję, genetycznie związaną z etyką zawodową, ale przenikającą i wiążącą w jedną zorganizowaną całość często różne zawody. Chodzi o zjawisko lawinowego wręcz narastania kodeksów etycznych korporacji biznesowych i instytucji życia publicznego. Etyka stała się w ten sposób quasi-prawem, regulatorem zachowań wpisanym w zadania ludzi zatrudnianych i funkcjonujących na różnych szczeblach organizacji życia społecznego. Można ją nazwać etyką instytucjonalną lub korporacyjną.

Powyższy stan rzeczy sprawia, że to, co rozumie się przez pojęcie „etyka”, daje się współcześnie rozbić na dość złożoną hierarchiczną strukturę. U jej podstaw tkwi etyka ogólna jako nauka filozoficzna (poniekąd także teologia moralna, która analizuje ludzkie problemy moralne w świetle objawienia). Etyka ogólna uzyskuje w ostatnich dziesięcioleciach bardzo bogate rozwinięcie w licznych etykach szczegółowych, przy czym proces ten może być traktowany mniej lub bardziej drobiazgowo. Przyjmijmy, że etyka szczegółowa koncentruje się na ważnych, wartych pogłębionej refleksji i unormowań aspektach ludzkiego życia i współżycia. To pozwala wyróżnić etykę indywidualną i społeczną, ale obie współzależne sfery życia dają się jeszcze bardziej rozczłonkować. Etyka indywidualna może być traktowana jako biotechnika (etyka osobowa, sztuka życia doskonałego i szczęśliwego), ale także jako etyka relacji międzyosobowych. W jednym i drugim wymiarze etyki szczegółowej pojawiają się dodatkowo ważne sfery stanowiące jądro zainteresowań etyki seksualnej, etyki pracy czy etyki obywatelskiej. Na terenie etyki społecznej niezwykle żywo rozwijane są: etyka ekologiczna, bioetyka, etyka nauki i postępu technicznego, etyka biznesu, etyka socjalna, etyka życia publicznego, w tym etyka mediów. Szczegółowe etyki wzajemnie się przenikają, jako że dziedziny życia, aspekty funkcjonowania człowieka wzajemnie się przenikają. Biznes może być medialny, oparty na wykorzystaniu osiągnięć nauki i postępu technicznego, funkcjonujący w konkretnej rzeczywistości określonej przez politykę, realizowany przez mężczyzn i kobiety przebywających i ciągle komunikujących się 
w pracy. Każda z etyk szczegółowych jest tylko wyabstrahowanym do pewnego stopnia przedmiotem badań i regulacji etycznych.

Etyka biznesu jako etyka szczególowa może z kolei dzielić się dalej, wykorzystując pewne obszary działań biznesowych w rodzaju: etyka marketingu, etyka ubezpieczeń, etyka doradztwa, etyka rachunkowości itp. Tak pomyślana etyka szczegółowa i jej dalsze uszczegółowienia mają na uwadze przynajmniej dwa zadania. Pierwsze polega na rozumiejącym opisie dziedziny biznesu w języku wartości w niej realizowanych, co znaczy, że charakterystyczne dla niej stosunki pracy i współpracy opisuje się jako działalność celową, racjonalnie dobierającą środki do celu, a także jako sferę możliwych dla niej konfliktów wewnętrznych i zewnętrznych. Drugie zadanie polega na krytycznej rekonstrukcji etosu środowiskowego, jeśli taki istnieje, a w każdym razie na normatywnym ujęciu powinności moralnych właściwych dla opisywanej działalności. To drugie zadanie wiąże etykę szczegółową z etyką zawodową, stanowiąc podstawy jej oceny i rekonstrukcji.

Etyki zawodowe mają wybitnie normatywny i zinstytucjonalizowany charakter. Ten sam status mają etyki korporacyjne, które należy rozumieć jako z jednej strony tzw. etyki wolnych zawodów, a z drugiej jako etyki korporacji biznesowych. Za etyki zawodowe można też uznać etyki służb publicznych (administracji, wojska, straży granicznej, policji itp.). Wszystkie one wpisują się w porządek prawny i funkcjonują za przyzwoleniem, a nawet pod nadzorem prawa lub ze skutkiem prawnym. Ale właśnie tutaj zrywa się więź aksjologiczna i metodologiczna z etyką ogólną i - co ważne - słabnie kontakt z etyką szczegółową. Twórczość kodyfikatorska w tym zakresie, oparta nierzadko na bezmyślnym naśladownictwie, wymuszana przez potrzeby wizerunkowe, sprawia, że trudno czasem w poszczególnych kodeksach i programach etycznych dopatrzyć się głębszej myśli (racji) etycznej, sensu porządkującego aksjologicznie, normatywnie i semantycznie zalecenia. Podstawową wadą tych kodeksów jest intuicyjność terminów, takich jak rzetelność, sumienność, bezstronność, obiektywizm, neutralność, unikanie konfliktu interesów, uczciwość, sprawiedliwość - często występujących obok siebie jako składniki odrębnych zasad. Inną wadą kodeksów jest mieszanie języka opisowego z wartościowaniem i dalej - rozmywanie normatywnej funkcji deontologii zawodu. Nie wiadomo czasem, czy kodeksy opisują rzeczywiste, czy pożądane (powinne) zachowanie ludzi. Swobodna, nieprofesjonalna twórczość etyczno-zawodowa sprawia więc, że kodyfikacje etyczne trudno odróżnić od regulaminów pracy czy osobowych zakresów odpowiedzialności pracowniczej. Zjawisko to obserwowane pobieżnie w Polsce wymagałoby systematycznych badań, zwłaszcza pozytywnej (to jest twórczej) krytyki kodeksowej etyki zawodowej i korporacyjnej. Ta druga (korporacyjno-biznesowa) wkracza na teren polskiego biznesu i życia publicznego za pośrednictwem amerykańskich i zachodnioeuropejskich organizacji gospodarczych oraz innych instytucji, wzorując się na nich, ale trafia na polską mental- 
ność moralną z różnym skutkiem. Znane są przykłady poważnego podejścia do etycznych wymogów uprawiania zawodu, do pracy i współpracy w biznesie, ale i nierzadkie są przypadki formalnego podejścia (zaliczenia okresowego testu, naśmiewania się z tego „niepotrzebnego balastu” w stosunkach pracy) ${ }^{1}$. Formułowaniem kodeksów dla zawodów i instytucji, a także refleksją nad problemami etycznymi środowisk zaczęli zajmować się nie tylko filozofowie moralności, ale także specjaliści innych dyscyplin humanistycznych i społecznych. W proces ten włączyli się, co jest samo w sobie interesujące, rozmaici moraliści, czyli uczestnicy debat o problemach moralnych różnych dziedzin życia społecznego, wśród nich autorytety zawodowe i osoby publiczne.

Zdarza się, że etyka jest instrumentalnie traktowana na użytek bieżących celów politycznych czy biznesowych, a to bynajmniej moralności nie służy. Łatwo bowiem ludziom rozpoznać moralny pozór motywów tej niebywałej troski o moralność. Toteż efekt tendencji do sztucznego, wyolbrzymionego nagłaśniania aspektów moralnych różnych dziedzin życia, kodyfikowania i reglamentowania wszystkiego w stosunkach biznesowych i publicznych bywa zazwyczaj mizerny i powinien skłaniać do gruntownego przemyślenia rangi etyki w poszczególnych dziedzinach życia społecznego, a także edukacji etycznej elit i moralistów wykorzystujących etykę do realizacji celów wizerunkowych w polityce czy biznesie.

Narzuca się zatem pytanie: czy można $z$ sensem mówić o etyce w sytuacji, kiedy jej obecność ma wymiar wyłącznie instrumentalny? Tymczasem etyce jako profesjonalnej nauce filozoficznej dotyczącej moralności (etosu, obyczaju) chodzi nie tyle o obecność etyki jako zespołu norm regulujących zachowania pracownicze, wpływające na odpowiedzialność etyczną przedsiębiorstw, ile bardziej i źródłowo o moralność stosunków biznesowych i publicznych jako autoteliczny i zarazem skutkujący w dziedzinie gospodarki i życia publicznego czynnik regulatywny.

$\mathrm{Za}$ fundamentalny i zarazem niedoceniany $\mathrm{w}$ dyskusji o etyce zawodowej uznaję moralny wymiar stosunków pracy i współpracy. Moralność, w odróżnieniu od etyki, z istoty swej ma charakter subiektywny, sumieniowy, bardziej osobowy i osobisty, bo zakłada chcenie dobra, chcenie spełnienia obowiązku, chcenie poszanowania norm społecznie akceptowanych. Mówiąc inaczej, moralność w tym ujęciu zakłada rzeczywiste podmiotowe przekonanie o wartości lub słuszności określonych postaw, etyka natomiast - kładzie nacisk na posłuszeństwo dla norm,

${ }^{1}$ Świadczą o tym wypowiedzi w dyskusjach na zajęciach MBA (przy Wydziale Nauk Ekonomicznych i Zarządzania), w których bardzo często biorą udział pracownicy polskich oddziałów korporacji amerykańskich i europejskich. Rozpoznanie mechanizmów i efektów wpływu zewnętrznych wobec polskiej rzeczywistości organizmów biznesowych i publicznych można uznać za interesujące interdyscyplinarne zadanie badawcze. Pewne rozpoznanie badawcze wykonała między innymi Anna Lewicka-Strzałecka i opublikowała w książkach: Etyczne standardy firm i pracowników, Warszawa 1999, oraz Odpowiedzialność moralna w życiu gospodarczym, Warszawa 2006. 
standardów, zasad moralnych określonych w kodeksach lub społecznie uznanych za autorytatywnie wiążące. Moralność dyktuje nam z wnętrza naszego sumienia, jak powinniśmy się zachować, o ile sumienie nasze jest dostatecznie wrażliwe i rozważne. Etyka wkracza do naszego postępowania z zewnątrz, wymaga sumienia respektującego przyjęte $\mathrm{w}$ środowisku normy moralne, mając do dyspozycji sankcje często współdziałające $z$ systemem prawnym. Etyka może służyć sumieniu jako wskazówka, może dawać mu do myślenia w przypadku konfliktu moralności i etyki, ale może też przez nadmiar formalizmu czynić to sumienie bezwzględnie posłusznym i stępiać jego wrażliwość, osłabiać zdolność podejmowania nieszablonowych decyzji w skomplikowanych sytuacjach, a czasem eliminować słuszny sprzeciw wobec błędnych etycznie poleceń czy rozkazów.

Zdaniem socjologów tzw. ponowoczesności etyka ma wybitnie charakter represyjny, to teoretyczna i metodologiczna podstawa „etycznego prawodawstwa”2. Myślę, że postmoderniści uprościli sobie obraz etyki normatywnej, dostosowując go do potrzeb swojej wizji historii, pomijając inne wymiary etyki, które czynią z niej narzędzie poszukiwania prawdy lub słuszności moralnej. Problem polega nie na tym, aby odrzucić etykę kodeksową jako formę etyki zawodowej, aby ograniczyć to tzw. „etyczne prawodawstwo”, ale znaleźć miejsce zarówno dla etyki normatywnej, jak i dla moralności, jako dwu stale oddziałujących na siebie składników kształtowania postaw. Mają na to wpływ odpowiedzi na pytanie o to, dlaczego powinienem być moralny w biznesie. Etyka filozoficzna pozwala wysunąć tu trzy nieredukowalne do siebie stanowiska.

Pierwsze odwołuje się do argumentu z opłacalności (dla oceny całości życia, ale także dla powodzenia i wizerunku firmy). Argument ten jest najczęściej stosowany przez tych, którzy działalność gospodarczą zamykają w granicach rachunku ekonomicznego. Jeżeli nieuczciwość opłaca się, jak często sądzą sezonowi biznesmeni, to po co być uczciwym. Trudno to stanowisko uznać za etyczne, raczej-za prakseologiczne.

Drugie stanowisko odwołuje się już wyraźnie do etyki, bo powołuje się na kodeksy i zasady etyczne, kładzie nacisk na imperatywny charakter moralności i sumienie posłuszne treści norm etycznych. Moralność sprowadzona zostaje tu do posłuszeństwa autorytatywnym normom, ufundowanym na porządku metafizycznym (religijnym), na porządku społeczno-prawnym lub na autorytecie głosu rozumnej natury ludzkiej. Ten ostatni fundament, znany z filozofii moralnej Immanuela Kanta (1724-1804), zbliża nas bardziej do współczesnego pojmowania moralności, która $\mathrm{z}$ pozycji sumienia liczy się z uniwersalnym, zdystansowanym

\footnotetext{
${ }^{2}$ Por. Z. Bauman, Etyka ponowoczesna, Warszawa 1996. Polecam zarazem analizy zawarte w pracy: W. Zieliński, Status etyki w kulturze ponowoczesnej. Analiza propozycji Zygmunta Baumana, Wydawnictwo Adam Marszałek, Toruń 2001. Por. także Z. Bauman, Dwa szkice o moralnośi ponowoczesnej, Warszawa 1994.
} 
wobec osobistego interesu dobrem moralnym. We wszystkich przypadkach motyw posłuszeństwa prawu moralnemu jest niezwykle silny, skądkolwiek nakazy te nie czerpałyby swego uzasadnienia.

Trzecie stanowisko nawiązuje również do filozofa z Królewca, ponieważ prowadzi nas do odpowiedzi, że racją naszej uczciwości powinna być godność moralna. Tę godność rozpoznajemy w sobie i w innym człowieku często w sytuacjach negatywnych, polegających na redukcji innego i w konsekwencji także siebie do wymiaru czysto użytkowego (prakseologicznego lub hedonicznego). Nie dlatego zatem zachowujemy się moralnie, że respektujemy nakazy, ale z głębi rozpoznania wartości absolutnej w doświadczeniu godności cudzej i własnej. W tym samym kierunku idą dziś ci etycy, którzy rozwijają etykę dialogiczną, etykę spotkania, etykę doświadczenia odpowiedzialności za Innego.

Często usiłuje się współcześnie całą moralność sprowadzić do przyjęcia etyki i postawy odpowiedzialności. Może to wywierać wpływ także na pojmowanie społecznej odpowiedzialności biznesu. Rzecz jednak w tym, że odpowiedzialność społeczna nie tylko nie może być oderwana od odpowiedzialności moralnej (i etycznej), czego się właściwie nie robi, ale warto zwrócić uwagę, że u podstaw odpowiedzialności społecznej tkwi odpowiedzialność moralna (i etyczna) we wszystkich wyżej naszkicowanych wymiarach. Pierwsza jest odpowiedzialnością w relacji do rachunku strat i zysków, druga w trybie poszanowania norm moralnych społecznie uformowanych w postaci etyki normatywnej (kodeksowej), trzecia w trybie relacji do ludzkiej godności jako zasadniczego źródła i kryterium moralności.

\section{KRYTERIA WARTOŚCIOWANIA PRACY}

Przyjmujemy, że miejsce pracy i właściwy dla rodzaju pracy zawód funkcjonują ze swej istoty w przestrzeni moralnej. $\mathrm{Na}$ czym zatem polega ów moralny aspekt przestrzeni pracy i samej pracy? Wymienię trzy kryteria, które poddam dyskusji:

Harmonizowanie użytkowej i moralnej wartości pracy. Postrzega się na ogół pracę jako wartość użytkową, bo ona czemuś służy, coś wytwarza. Dla pracownika jest ona środkiem utrzymania siebie, a z czasem także rodziny. Praca jest jednak dobrem przekraczającym wymiar użytkowy; rozumiemy przez to, że jest istotnym składnikiem sposobu życia. Praca definiuje człowieka. Zawód od wieków bywa rozumiany jako życiowe powołanie człowieka. Jest się po prostu tym, co robi się w życiu, z czego ktoś się utrzymuje. Do podstawowej charakterystyki osoby należy określenie jego zawodu. Krawiec, górnik, lekarz, urzędnik, menedżer, naukowiec, poeta, reżyser - to ważne uzupełnienia dookreślające czyjąś identyfi- 
kację. Czymś ujemnym dla osobowej charakterystyki jest być człowiekiem bez zawodu, bez umiejętności wykonywania jakiejś pracy. To prawie tyle, co być próżniakiem lub pasożytem, w najlepszym razie nieudacznikiem.

W miejscu pracy i procesie pracy realizuje się ta podwójna wartość, jaką stanowią w ścisłym związku ze sobą: użyteczność pracy (jej wartość względna) i godność pracy (wartość bezwzględna). Wydaje się czasem, że cała wartość pracy płynie z jej użyteczności, z tego, czemu służy, do czego prowadzi, co warunkuje. W takim ujęciu praca miałaby jedynie wartość względną. Praca bezużyteczna lub destrukcyjna byłaby tej wartości pozbawiona, miałaby tym samym wartość względną ujemną. Mówimy czasem, że praca taka jest bez sensu, a nawet, że to jest zła praca. Przypisujemy jednak pracy wartość bezwzględną w innym wymiarze, już niezależnym od konkretnych związków pracy z jej celem wytwórczym. Przypisanie pracy wartości bezwzględnej, zarazem dodatniej, mieści się w ogólniejszym, gatunkowym punkcie widzenia istotnie wiążącym bycie człowiekiem z pracą jako sposobem samorealizacji. Mówiąc inaczej, moralna godność osiągnięć ludzkich jest tu ściśle wiązana z pracą wkładaną w to, co osiągnął i kim $\mathrm{w}$ rezultacie swej pracy jest. Zatem godność pracy przypisana jest poniekąd z góry ludzkiemu istnieniu, a jej użyteczność godność tę wzmacnia lub destruuje. Powołaniem człowieka, jego godnością jest praca, co pozostaje w sprzeczności z cwaniackim pozorowaniem pracy, umiejętności zawodowych, osiągnięć życiowych, aspirowaniem do zasług. To bodajże najistotniejszy czynnik generujący także godność zawodową jako postawę moralną, a w konsekwencji - etykę zawodową. Zatrzymajmy się chwilę przy tym nieco filozoficznie ujętym spojrzeniu na pracę jako moralne źródło godności człowieka.

Praca konstytuuje godność moralną człowieka, a ta jest nadbudowana nad jego godnością naturalną ( $\mathrm{z}$ urodzenia przysługującą ludzkiej istocie). $Z$ tytułu godności naturalnej z troską odnosimy się do ludzi trwale niezdolnych do pracy, następnie i do tych, którzy zostali pozbawieni pracy. Pamiętamy też czasy, kiedy pod hasłem moralnej wartości pracy demoralizowano pracę przez tworzenie bezużytecznych, mało wydajnych miejsc pracy. Tę chorą pracę opisywał i poddawał krytyce ks. Józef Tischner w Etyce solidarności około trzydzieści lat temu3. Miarą zdolności systemu społecznego do generowania ładu moralnego wydaje się walka ze stosunkami, które demoralizują pracę, pozbawiają ją treści moralnie ważnej dla poczucia osobistej godności człowieka. Rdzeń moralny człowieka zdaje się więc wynikać z jego stosunku do sposobu konstytuowania siebie samego, do samo-integracji, samorealizacji poprzez pracę, poprzez zawód, jaki wykonuje. Człowiek, który lubi swoją pracę, lubi także siebie i to przenosi na innych. W wartościowa-

${ }^{3}$ Por. J. Tischner, Etyka solidarności, Wydawnictwo Znak, Kraków 1981; także w tomie: Etyka solidarności i Homo sovieticus, Wydawnictwo Znak, Kraków 1992. 
niu pracy ujawnia się istotna treść moralna, przenoszona na inne stosunki społeczne. Człowiek samo-konstytuujący się przez pracę, wnoszący jej wartościowanie i owoce do stosunków $\mathrm{z}$ innymi, w zasadzie nie potrzebuje kodeksu etycznego jako przewodnika moralnego, choć warto wiedzieć, co kodeks zaleca, czego zakazuje w środowisku pracy, co wspólnota uznaje za powinne moralnie w zawodzie. Nasza świadomość moralna może przecież czasem coś przegapić, po prostu przysypiać, a nawet co gorsza, popadać w pychę nieomylności.

Nie wszyscy tak to rozumieją. Lekceważący stosunek do pracy jako wartości określającej moralny wymiar życia sprawia, że gloryfikujemy inne, często przeciwne wartości: chętnie oddajemy się lenistwu; mówimy, że człowiek urodził się nie po to, aby pracować; że sztuka życia polega na tym, aby się nie napracować, a mieć. Takie postawy nie mają wsparcia ani w religiach, ani w głównych systemach myśli filozoficzno-etycznej, są raczej żywiołowe, uciążliwe swoją hałaśliwą bezmyślnością, stanowiąc poważne źródło deficytu moralności pracy i współpracy. Znamy to z codziennego doświadczenia, a socjolodzy wiedzą dokładniej, jaka część społeczności tak myśli. Tu moralistyka i kodeks etyczny wydają się mało użyteczne, choć czasem wkraczają jako czynnik dyscyplinujący.

Potrzeba kodeksu etycznego w sytuacjach generowanych przez lekceważenie wartości pracy lub moralnego wymiaru pracy ujawnia się szczególnie w etyce zawodowej, lekceważący stosunek do pracy uderza bowiem w misję zawodu, w godność zawodową, podważając zaufanie do zawodu. Moralna godność zawodu jest nową kategorią w naszym współczesnym myśleniu o etyce zawodowej. Tak rozumiana godność, jeśli się pojawia w świadomości ludzi określonego zawodu, posiada o wiele większą siłę motywacyjną, korygującą zachowanie ludzi danego zawodu, niż kodeks etyczny. O ile poczucie godności zawodowej - jakoś związane z poczuciem godności osobowej - jest z gruntu przeżyciem moralnym, o tyle etyka zawodowa i kodeksy etyczne są pożyteczne przez to, że definiują kryteria godności danego zawodu. To pomoc, punkt odniesienia dla „sumienia zawodowego”, którego bynajmniej nie powinno się lekceważyć.

Traktowanie cudzej pracy w sposób godziwy - to drugie kryterium moralnego aspektu kształtowania przestrzeni pracy i samej pracy. Praca innego człowieka, kolegi, podwładnego, zwierzchnika, kooperanta zachowuje w relacjach międzyludzkich tę samą podwójną wartość użytkową i moralną. Na harmonizacji tych wartości tu także polega jej godziwość. Wyjaśnijmy to dokładniej: użytkowa wartość pracy ma swój wymiar zarówno rzeczowy, jak i finansowy. $Z$ tego powodu mówi się o wynagrodzeniu godziwym, czyli odpowiadającym wartości użytkowej pracy. Ale nie tylko wartość użytkowa pracy kształtuje wynagrodzenie. Ekonomiści wiedzą i ciągle nam przypominają, że zależy ona także od całego złożonego układu stosunków ekonomiczno-organizacyjnych, średnich kosztów utrzymania pracownika i jego rodziny, rynku pracy - i zapewne jeszcze od innych czynników. 
Godziwe, godne traktowanie cudzej pracy związane jest ponadto ze sprawiedliwym podziałem zadań w pracy i odpowiednio do tego równym jej wynagradzaniem. $Z$ kolei niesprawiedliwe traktowanie pracownika odziera go z godności, ponieważ okazuje się brakiem szacunku dla jego pracy. Tak samo niesprawiedliwie postępuje ten, kto nie dba o miejsce pracy, jego ergonomię, bezpieczeństwo, higienę, o respektowanie praw pracowniczych i o wiele innych aspektów funkcjonowania miejsca pracy. Godność w miejscu i stosunkach pracy daje się przeto ująć bardzo konkretnie. Kto nie dba o poszanowanie wartości moralnych wspó1-konstytuowanych przez pracę, redukuje wartość pracownika do bilansu użytków, jaki ma $z$ jego czasu, sił, umiejętności, talentu. To jest klasyczna redukcja do użytku, zaprzeczenie uznania godności pracy i godności człowieka.

Sztuka kształtowania moralnego klimatu w pracy polega tu znowuż na tym, by w pracowniku widzieć coś więcej niż wartość użytkową, a więc koniecznie trzeba widzieć w pracowniku nie zespół sprawności, które się kupuje, ale oprócz tego „kogoś”. Pracownicy to nie tylko „zasoby pracy”, które można i trzeba wyeksploatować, a następnie - co się zwykle dzieje - zwolnić lub odesłać na emeryturę. Niestety, język ekonomiczny, oszczędny w słowach, sprawia, że tracimy z pola widzenia moralny wymiar ludzkiej pracy i stosunków pracy. Nawet termin „moralny” został zekonomizowany, kiedy zaczęto go odnosić do tzw. „moralnego” zużycia maszyn.

Wartości moralne pracy i stosunków współpracy to jakości wprost niewidoczne, ale przejawiające się $\mathrm{w}$ efektach pracy. Badania socjologiczne opisują to zapewne dokładniej, ale codzienna obserwacja przekonuje, że niegodnie, przedmiotowo, użytkowo tylko traktowany pracownik popada w stany frustracji, częściej choruje, powiększając skalę absencji w zakładzie pracy. Spada też jego zdolność do zaangażowania, innowacyjności - słowem, pracownik staje się coraz mniej przydatny w przedsiębiorstwie i coraz mniej zadowolony z siebie. Znowuż widać, jak dezorganizacja przestrzeni moralnej miejsca pracy, nieumiejętność zarządzania klimatem moralnym w pracy niszczą potencjał możliwości pracowniczych i niszczą zarazem moralną godność pracy.

$Z$ tej perspektywy nie ulega wątpliwości, że pracodawcy, menedżerowie, kadra kierownicza instytucji i przedsiębiorstw ponoszą największą odpowiedzialność za klimat moralny w pracy i za wszystkie tego dalsze następstwa. Polskiej kadrze, jak mogłem się nieraz przekonać, a wiem to $z$ relacji moich pracujących studentów, na ogół brakuje zrozumienia dla moralnych aspektów pracy i organizacji miejsca pracy. Od kadry zatem należy rozpocząć uświadamianie znaczenia wdrażania programów etycznych do zakładów pracy, firm, instytucji. Liderom biznesu i managementu stawia się przecież już od pewnego czasu zadanie przewodzenia w odpowiedzialności społecznej i etycznej. 
Stosunek do dobra wspólnoty - wyznacza trzecie kryterium moralnego wymiaru przestrzeni pracy. Użytkowa wartość pracy wielu ludzi, ich zawodowa działalność, współtworzy i pomnaża w jakimś stopniu całość organiczną w postaci wspólnego dobra. Myślenie kategoriami interesu wspólnego jest znakiem spoistości moralno-prawnej każdego społeczeństwa i postępu w tej mierze. W toku długich lat zaborów, a potem w czasie "pozornego socjalizmu” nasz polski jednostkowy stosunek do dobra wspólnego rozwijał się w niezwykle trudnych warunkach, a nawet uległ postępującej demoralizacji, mimo bezprzykładnych wielkich zrywów powstańczych i solidarności ludzi pracy. Być może to jest subiektywne przekonanie, ale nie bardzo widać, abyśmy zdecydowanie weszli na dobrą drogę wspólnotowego myślenia o racjach zachowań moralnych, szacunku dla prawa, identyfikowania się z interesem wspólnoty uformowanej w państwo. Mimo to żyjemy w nadziei, że uda nam się wynieść ponad osobisty egoizm partykularyzm zawodowy, branżowy, terytorialny, że nauczymy się negocjować nasze interesy z uwzględnieniem dobra wspólnego jako sumarycznego i zharmonizowanego wyrazu wielkiej zorganizowanej pracy i postaw obywateli. Przezwyciężyć nie znaczy tu wyrzec się interesu partykularnego, który jest siłą napędową działań ludzkich, ale zdystansować się od wyłącznie partykularnego spojrzenia na konflikty interesów, jakie w życiu społecznym nieustannie się rodzą. Nie chodzi o bezinteresowność postaw pracowniczych, zawodowych, społecznych, ale umiejętność wzniesienia się ponad interesy (ponad-interesowność) osobiste lub grupowe. Teorie społeczne i etyka społeczna mówią tu o bezinteresowności, co wydaje się nieadekwatne w stosunku do tego, o co tu właściwie chodzi. Tzw. bezinteresowność zakłada nierealną naturę ludzką. Powtarzam, nie o to chodzi, aby wyrzekać się zainteresowania czymś, interesu osobistego, ale o to, by interes ten jasno zdefiniować i ocenić, a następnie, aby umieć go bronić nie przeciw wspólnocie i jej ewidentnym kosztem, a jeśli trzeba, umieć swój osobisty interes wkomponować w interes wspólnoty, bądź nawet poświęcić ten interes dla dobra wspólnego, jeśli ono rzeczywiście jest przekonujące jako wspólne. W Polsce publiczna debata o relacji dobra jednostki i dobra wspólnego ciągle jeszcze raczkuje, choć można wskazać $\mathrm{w}$ literaturze interesująco zarysowane płaszczyzny dyskusji i potrzebną do tego aparaturę pojęciową ${ }^{4}$.

Nie ulega wątpliwości, że czynniki wzmacniające postawy wspólnotowe mają źródło nie tylko w etycznych ramach funkcjonowania przedsiębiorstw i instytucji, ale przede wszystkim tkwią w szeroko rozumianym funkcjonowaniu całego systemu instytucji społeczeństwa obywatelskiego. Psycholodzy społeczni biją na alarm, publikując wyniki badań wskazujących na głęboki indywidualizm Polaków, nie-

${ }^{4}$ Por. A. Szahaj, Jednostka czy wspólnota? Spór liberatórw z komunitarystami a "sprawa polska”, Fundacja Aletheia, Warszawa 2000. 
zdolność do współpracy, niezdolność do rozumienia pożytków współdziałania. Być może źródłem tak niewielkich postępów w naprawie Rzeczypospolitej, jej praw, jej władz i postaw jej obywateli są politycy, ale zapewne udział w tym mają także ludzie mediów. Widać tu zupełny deficyt profesjonalizmu zawodowego i brak odpowiadającej każdemu profesjonalizmowi kompetencji etycznej, w miejsce której pojawia się dziennikarskie moralizatorstwo. Razi nadmierny partykularyzm, stronniczość, zupełna niezdolność do przyznania racji przeciwnikowi politycznemu czy konkurentowi w interesach, co bywa podsycane przez dziennikarzy i podnoszone do poziomu kłótni. Niedobry klimat moralny współtworzy niekompetencja merytoryczna, instrumentalne traktowanie języka moralności i etyki $\mathrm{w}$ retoryce i walce wyborczej, nieuzasadniona wiara w siłę marketingu politycznego i specjalistów od sztuki kształtowania wizerunku. Zamiast sprawowania mądrych i uczciwych rządów, liczni, zbyt liczni, politycy uciekają się do populistycznych zabiegów opartych na poradach formułowanych przez często wyzbytych zasad przyzwoitości moralnej ekspertów od tworzenia pozorów lub retuszowania rzeczywistości. Etykę życia publicznego i etykę zawodową wypiera wiara w magiczną moc marketingu politycznego. Pocieszmy się, że nie jest to wada tylko naszych polityków i mediów.

Nie zwalajmy zbyt wiele na medialno-polityczny teatr w naszym kraju. Wiara $\mathrm{w}$ techniki marketingowe $\mathrm{w}$ sferze ekonomicznej toczy się na podobnym poziomie. $Z$ czysto etycznego punktu widzenia niepokoi nadmiar ufności pokładanej w mocy kampanii reklamowych kosztem strategii skierowanych na poprawę jakości towaru i obsługę klienta. Kosztowny trik marketingowy wyrażający się w sloganie reklamowym „Nie dla idiotów” jest zakamuflowaną formą pogardy dla klienta, bo jeśli się na to nabierze, to w jakimś stopniu jest idiotą, daje się zmanipulować, a manipulacja wyborami rzesz klientów to dobitny wyraz nieliczenia się ze wspólnotą . Mimo pewnej sanacji w pojmowaniu misji marketingu, deklarowanego zaangażowania na rzecz dobra klienta, adepci różnych zawodów ulegają wierze w rozstrzygającą skuteczność jego agresywnych form. Tymczasem, jakkolwiek stosunki ekonomiczne są fundamentem funkcjonowania społeczeństwa, bynajmniej racjonalność ekonomiczna i wartości w tej dziedzinie funkcjonujące nie

${ }^{5}$ Tak przynajmniej widzi to zwykły krytyczny klient. W markecie „Nie dla idiotów” jakość towaru nie różni się przecież od tego samego towaru sprzedawanego gdzie indziej, ceny też się specjalnie nie różnią, obsługa często gorsza niż w innych sklepach, bo trudno w zatłoczonym markecie ją znaleźć, ale jaka radość może płynąć z tego, że kupuje się w sklepie, do którego idioci nie są zapraszani. W cenie towarów ukryta jest przecież kosztowna kampania ogłupiająca klientów. Ktoś tę pracę ogłupiania wykonuje. Praca ta może jest dobra dla sieci handlowej, dla ludzi ją wykonujących (mają pracę), ale już wątpliwe jest, czy jest to dobre dla wspólnoty, jej systemu wartości, kosztów zakupu towarów. Agresywna reklama zastępuje porządną i łatwo dostępną informację oraz obsługę. Ogłupianie klientów w strategiach marketingowych to wielkie zagrożenie dla osobowości pokoleń bezmyślnie reagujących na reklamę. 
powinny dla dobra społeczeństwa kształtować żywiołowo jego systemu. Potrzebne jest wychowanie do konsumpcji, a przede wszystkim wychowanie człowieka do udziału w społeczeństwie produkującym w obfitości dobra konsumpcyjne ${ }^{6}$.

Wartości produkcyjno-konsumpcyjne są ważne jako fundamentalne dla procesu społecznego, ale nie mniej ważne są wartości wyższe, które na tym fundamencie się wznoszą i nasycają troską o wspólnotowy system wartości i moralności. Uleganie oddolnej presji żywiołowo kształtujących się stosunków społecznych bezkrytycznie ulegających marketingowi grozi cywilizacyjną eskalacją pozoru do poziomu, który może skutkować podobnie jak niedawne załamanie wiary w zdolność kredytową czy wiarygodność finansową uczestników rynku finansowego. Nie brakuje opinii, że jest to nowy ruch totalizujący życie społeczne. $Z$ etycznego punktu widzenia ignorowanie wartości moralnych tkwiących w samym jądrze zjawisk ekonomicznych, lekceważenie etyki zawodowej, musi z konieczności zaowocować funkcjonalną utratą zaufania do wszelkich komunikacyjnych i marketingowych przekazów wartości. To złamanie proporcji między realnymi wartościami towarów i usług, zachłyśnięcie się sztucznym windowaniem ich pozycji na rynku nie może pozostać na dłuższą metę bez skutków. Ktoś kiedyś za to będzie musiał zapłacić. Stąd płynie troska o społeczną i etyczną odpowiedzialność biznesu.

\section{FORMY I PROBLEMY ZARZĄDZANIA KLIMATEM MORALNYM W PRACY ZAWODOWEJ}

Remedium na deficyty społeczno-etyczne zachowań w środowisku biznesu upatruje się w programach społecznej odpowiedzialności biznesu. Tzw. CSR (Corporate Social Responsibility) dociera coraz powszechniej do przedsiębiorców i kształtuje ich sposób zarządzania biznesem. Patrzymy z ufnością w ten proces. Obejmuje się bowiem tym programem różne kręgi interesariuszy wewnętrznych i zewnętrznych. Wszystkie kręgi, jakkolwiek pojęte, wiążą się z wartościowaniem ludzkiej pracy, także w wymiarze wspólnotowym. Byłoby jednak nieporozumieniem, gdyby programowi temu odbierać toczący się w innej płaszczyźnie niż odpowiedzialność etyczna i najgłębiej pojęta odpowiedzialność moralna. Znaczyłoby to bowiem, że relacja społeczna jest indyferentna źródłowo względem moralnych postaw i etycznych standardów. Nie wnikając w ten temat szczegółowo, trzeba powiedzieć, że trudno wyobrazić sobie przedsiębiorców, kadrę kierowniczą, pracowników, także akcjonariuszy, aby włączyli się w proces kształtowania

\footnotetext{
${ }^{6}$ Warto tu zwrócić uwagę na książkę Lesława Hostyńskiego Wartości w świecie konsumpcji, Wydawnictwo UMCS, Lublin 2006.
} 
odpowiedzialnych społecznie działań przedsiębiorstw, bez odpowiedniej motywacji moralnej. Ta oczywiście może powstawać intuicyjnie, może podlegać wymuszeniom środowiskowym, ale najlepiej jest, kiedy jest świadomie kształtowana. Do tego potrzebna jest edukacja etyczna wnosząca porządek pojęciowy do dyskusji o odpowiedzialności społecznej biznesu.

Przykładem pogubienia się w tym przedmiocie bywa nie tylko separowanie problematyki CSR od jej etycznych fundamentów, ale między innymi bezrefleksyjne odnoszenie tej odpowiedzialności do przedsiębiorstw jako osób prawnych. Rzecz w tym, że osoba prawna nie może mieć moralności, nie kieruje się sumieniem, lecz może być tylko odpowiedzialna na gruncie cywilno-prawnym lub administracyjno-karnym. Tymczasem cała hierarchiczna organizacyjna struktura osób prawnych obsadzona jest mniej lub bardziej odpowiedzialnymi osobami fizycznymi, które mają osobowość moralną czy inaczej mówiąc - podmiotowość moralną i w konsekwencji podmiotowość etyczną. To właśnie od osobowości osób fizycznych, ich kompetencji moralnej i kompetencji etycznej zależy złożony społeczny wymiar odpowiedzialności ${ }^{7}$. Ten zaś zawsze będzie wspierał się na moralności w przestrzeni pracy. W Polsce troska o moralną przestrzeń pracy jest w powijakach. Łatwiej wkraczać na teren CSR, co jest poniekąd programem wymuszonym przez międzynarodowy świat zewnętrzny, poniekąd wychodzącą temu naprzeciw modą, poniekąd kwestią wizerunkową, ale także wyrazem silnych przekonań moralnych. Temu procesowi należy się wsparcie etyki.

Warto jednak zapytać, czy etyka jest zdolna aktywnie uczestniczyć w kształtowaniu moralnej przestrzeni pracy i odpowiedzialności społecznej z tym związanej. Współczesna etyka rozszczepia się, jak zostało to pokazane, na etyki szczegółowe, ryzykując zagubienie ogólnego wymiaru normatywnego, wiążącego rozmaite role społeczne w jedną - bycie człowiekiem. Etyka zawodowa traci kontakt z etyką ogólną, postawy zawodowe, zachowania w pracy, w biznesie odrywają się od zachowań ogólnoludzkich. Dzieje się tak być może dlatego, że wobec wielości ról i wymagań etycznych z nimi wiązanych powstaje wątpliwość co do ich spójności, swoistej moralnej kompatybilności. Wiadomo, że różne role społeczne popadają ze sobą w konflikty. Bywa, że rola dobrej matki i dobrej pracownicy kłóci się ze sobą. Wiadomo, że zakaz kłamstwa uchodzi za taki,

${ }^{7}$ Etyka w naszych rozważaniach traktowana jako uporządkowany zbiór norm o treści moralnej, w swym podobieństwie do prawa, może być jednakowoż uznana za podstawę orzeczeń odpowiedzialności etycznej przedsiębiorstw, ale - nie odpowiedzialności moralnej, która jest osobowa, indywidualna. Za naruszenie godności osobowej pracowników, partnerów, klientów odpowiadają osoby, nie firma. Wydaje się to najzupełniej zrozumiałe, ale warto pamiętać, że trudno doszukać się tego właśnie zrozumienia w postawach osób, które w stosunkach pracy zapominają o własnej i cudzej godności, o odpowiedzialności, sumieniu. Do pewnego stopnia myślimy następująco: to instytucja niech się martwi, że naszych klientów oszukujemy, to sprawa firmy, że ich nie szanujemy. To instytucja ma podmiotowość w tym zakresie, my - nie. My tu tylko pracujemy. 
który obowiązuje człowieka bezwzględnie, ale mamy już wątpliwości, czy w biznesie, polityce lub gdzie indziej obowiązuje równie bezwzględnie. Wiemy, że poszanowanie godności człowieka jest najważniejszą normą w jakichkolwiek stosunkach międzyludzkich, ale w etosie menedżerskim ta norma nie cieszy się takim samym uznaniem. Zdehumanizowany wyraz ma przecież nomenklatura nauk i procesów, w której mówi się o zarządzaniu zasobami ludzkimi czy zasobami pracy. Mamy więc tu istotny problem, podnoszony przez przeciwników etyki szczegółowej i etyki zawodowej, polegający na zarzucie parcelacji etyki ze skutkiem relatywizowania jej do potrzeb określanych przez wartości danej dziedziny lub zawodu. Problem więc w tym, że albo rację mają zwolennicy jednej etyki ogólnej dla wszystkich aspektów życia, albo zwolennicy jej fragmentaryzacji w postaci etyk szczegółowych, zawodowych i instytucjonalnych, które lepiej rozumieją specyfikę poszczególnych aspektów życia w społeczeństwie. Wydaje się, że to przeciwstawienie nie ma sensu, że trzeba uczyć etyki, schodząc z poziomu ogólnego na poziom szczegółowej etyki i etyki zawodowej. Błąd tkwi w edukacji etycznej, która jeden z tych członów gubi. Nie o to przy tym chodzi, aby $\mathrm{w}$ proces edukacyjny $\mathrm{w}$ tym przedmiocie włączali się wyłącznie etycy, ale żeby każdy, kto chce to czynić, przyswoił sobie porządną porcję etycznej wiedzy ogólnej. Inaczej będzie to nieprofesjonalna moralistyka zawodu.

W tym kontekście wróćmy do rozróżnienia moralności i etyki, aplikując je do warunków przestrzeni wykonywania pracy i współpracy. Nasuwa się wniosek, że zarówno moralny, sumieniowy, wewnętrzny wymiar moralności, szanujący autonomię moralną jednostki, jak i wymiar etyczny, zinstytucjonalizowany w organizacji przedsiębiorstw, stanowią dwa niezbędne składniki właściwie przebiegającego procesu nasycania stosunków pracy i pochodnych relacji ekonomicznych wartościami moralnymi. Etyka zawodowa, kodeksy i standardy etyczne spółek stanowić winny otwarte na dialog sumień ramy procesu moralnego towarzyszącego codziennym stosunkom pracy. Aby to było możliwe, niezbędne jest ożywienie obecności wrażliwości moralnej i funkcjonowania infrastruktury etycznej w organizacjach gospodarczych. Do tego potrzebne jest etyczne lub raczej moralne przywództwo w biznesie, programy etyczne, które bynajmniej nie sprowadzałyby się do nakazowego administrowania sumieniami.

Skutecznym sposobem kształtowania moralności zawodowej są wzory osobowe. To punkt wyjścia dyskusji o przywództwie niepozbawionym aspiracji moralnych. Ale i tu problem polega na tym, że za wzór stawia się często nie tych, którzy sumiennością zawodową się wyróżniają. Mamy też w pamięci niedobrą, zafałszowaną historię promowania przodowników pracy. Ale współcześnie potrzeba stanowienia wzorów przejawia się w koncepcjach przywództwa w biznesie i jego moralnych lub etycznych składników. To rzeczywiście ważny instrument oddziaływania na moralność, o ile nie będzie naruszał „masy krytycznej” pozoru. Używa- 
jąc tu terminu „masa krytyczna”, chcę wskazać na zrozumienie realistycznej etyki dla potrzeby dbania o dobry wizerunek, co nieuchronnie rodzi drobne retusze postaw rzeczywistych: każdy stara się przedstawiać siebie lepszym, niż jest, i trudno to wytrzebić w ludzkich postawach. Pewien rodzaj makijażu etycznego daje się usprawiedliwić troską o integrację w działaniu społecznym, dostrzegalną zgodność ze standardami społecznie akceptowanymi, podobnie jak z modą i potrzebą bycia „trendy”. Granica makijażu zostaje przekroczona wtedy, kiedy oszustom udaje się przekonać otoczenie o swej nieposzlakowanej uczciwości. Wiadomo, że liderzy biznesu i managementu nie są świętymi, nie tylko zresztą oni, ale problem zaczyna się, kiedy nieskromnie próbują oni odgrywać role liderów etycznego biznesu. Wiele o tym mówią doświadczenia młodych pracowników opisywane i formułowane w postaci wniosków w projektach odpowiedzialnego biznesu opracowywanych na zajęciach MBA. Potwierdzają to analizy spektakularnych upadków wielkich firm, jak Enronu czy Andersena.

W każdą kompetencję zawodową zasadniczo powinna być wpisana kompetencja moralna i etyczna w sprawach dotyczących sprawnego wykonywania tego zawodu. Ale w epoce dominacji postaw pragmatycznych, tzw. „wyścigu szczurów”, związek kompetencji zawodowej i moralnej najczęściej nie idzie ze sobą w parze: wymóg skuteczności zdaje się kłócić z wymogiem moralności. Tak jednak nie jest. Podzieleni bywamy w opiniach o tym, co znaczy być dobrym lekarzem, dobrą pielęgniarką, dobrym menedżerem, dobrym pracownikiem. $Z$ pewnością nie wystarcza sprawność zawodowa. Niezbędny jest z jednej strony rzetelny stosunek do tego, co wchodzi w zakres kompetencji merytorycznej, sprawności, skuteczności, i co zwykle nazywa się rzetelnością, z drugiej strony w tym stosunku już wyrażana jest postawa szacunku wobec adresata naszej pracy zawodowej. Może by to już wystarczyło, aby dokładnie zrobić to, co należy, lege artis. Czy trzeba jeszcze czegoś extra dla spełnienia wymogu etycznego? - pytają niektórzy. Otóż rzeczywiście, rzetelność zawodowa jest nośnikiem wartości moralnej, ale wartości sprawiedliwości, polegającej na dawaniu tego, co się słusznie należy. Świat moralności nie zamyka się jednak w przestrzeni sprawiedliwości i jej pochodnych wartości. Świat moralności polega ponadto na dawaniu czegoś więcej, niż się należy, przynajmniej solidarności, życzliwości, przyjaźni i ich wielorakich odmian. To swoisty klimat, który sprzyja dobrym relacjom, uśmiechowi, czasem wyrozumiałości dla przypadkowego błędu, który może być naprawiony. To inna warstwa, trochę zaniedbana, ale warto ją wprowadzać w stosunki pracy, w kontakty - nie tylko w formie obowiązkowego „dzień dobry”. Nie mamy więc wątpliwości, że profesjonalizm to także etyka zawodowa, która powinna być nasycona nie tylko normami ze sfery sprawiedliwości, ale i życzliwością, która stanowi o otwarciu na podmiotowość partnerów zawodu, pracy, usługi, relacji służbowej. Tego 
jednak w trybie regulacji etycznych wprowadzić się nie da, gdyż nie można narzucać ludziom życzliwości.

\section{ZAKOŃCZENIE}

Widać więc wyraźnie, że traktowanie etyki jako zinstytucjonalizowanego instrumentu zarządzania klimatem moralnym w stosunkach pracy ma moc ograniczoną. Etyka rozumiana jako kodeksowa regulacja postaw moralnych określa standardy oczekiwanych zachowań pracowniczych, narzuca z zewnątrz kryteria oceny ludzi, zadowala się posłuszeństwem dla norm, staje się narzędziem administrowania postawami moralnymi, ignorując wewnętrzną, motywacyjną stronę postaw ludzi funkcjonujących w stosunkach pracy. Do istoty moralności należy właśnie to, że wypływa ona $\mathrm{z}$ wnętrza człowieka, $\mathrm{z}$ jego godności, wolności sumienia i poczucia odpowiedzialności. Tu rodzi się gotowość do autentycznego respektu dla dobrze uzasadnionych norm etycznych, poświadczanych postawami tych, którzy etykę zawodową promują z racji swych instytucjonalnych uprawnień do wpływania na ludzkie zachowanie. Klimatu szacunku dla etyki zawodowej czy instytucjonalnej nie da się osiągnąć bez zrozumienia natury stosunków pracowniczych i wartości ludzkiej pracy, bez analizy źródeł możliwych i zupełnie realnych konfliktów w przestrzeni pracy, bez przywództwa etycznego zbudowanego na dialogicznym i odpowiedzialnym sumieniu moralnym. Niezbędna jest też nieustanna edukacja etyczna (wiedza o etyce), pobudzająca refleksję moralną.

\section{THE MORAL SPACE OF LABOR AND PROFESSIONAL ETHICS}

SUMMARY

The article takes into consideration the problem of limited functions of professional ethics in the area of moral aspects of labor. The author takes as starting point of his considerations an internal variety of labor relations. Besides the economic aspect of labor and exchange of fruits of human labor, its moral aspect is considered as very important. An area of knowledge and instruments controlling the moral aspect of labor is ethics.

The author assumes the need of a clear distinction between ethics and morality. The author means (understands) by ethics an external normative system making criteria of human conduct. Morality is interpreted as an internal stimulator of human conduct based on conscience. The ethical dimension of human conduct depends on the internal moral approval of requirements of the normative system, if it expresses respect for labor and the dignity of man.

The moral space of labor is essentially connected with morality. An organization of labor tends to harmonize utility and market value with the moral (personal) dimension of 
labor. If man likes his work and feels its importance and honest assessment, he spreads this evaluation on the area of labor of other people and the good of the community. The author is convinced that human relations in the social space of labor essentially affect the moral attitudes of society, but its administration shouldn't constrain the instrumental and institutional functions of the code of professional ethics. Therefore the author claims that professional ethics need more moral reflection, ethical education and moral leadership in the area of labor relations. 